\title{
A COMPARATIVE STUDY OF BANKING EFFICIENCY IN ASEAN-5: THE DATA ENVELOPMENT ANALYSIS (DEA) APPROACH
}

\author{
Setyo Tri Wahyudi \\ Faculty of Economics and Business, Universitas Brawijaya, Indonesia \\ (setyo81@gmail.com) \\ Azizah \\ Faculty of Economics and Business, Universitas Brawijaya, Indonesia \\ (ziz4h92@gmail.com)
}

\begin{abstract}
As an intermediary institution, a bank is required to operate efficiently due to the increased competition among banks, both domestic and international. However, not all banks are able to optimize their owned resources to reach a certain efficiency level. Thus, efficiency plays an important role in this era of more globalized banking competition. The objective of this study is to calculate the banking efficiency score for the ASEAN-5 countries, consisting of Indonesia, Malaysia, the Philippines, Singapore, and Thailand. Using Data Envelopment Analysis (DEA), the input variables comprised of employees' benefits, fixed assets, and deposits; while the output variables were total income and loans. The results show the relatively high efficiency levels of every bank in each country. The achievement of an input-output efficiency variable in the first period (2006-2009) tended to increase, but the second period (2010-2013) showed a declining trend. The performance of the banks in Singapore during the first period was very good, while in the second period, the banks in the Philippines showed a respectable performance.
\end{abstract}

Keywords: banking efficiency, data envelopment analysis

JEL Classification: G17, C53 


\section{INTRODUCTION}

Efficiency is closely related to input and output, particularly when dealing with how an institution is able to optimally allocate production factors (inputs) to produce the maximum output. According to Muazaroh, Eduardus, Husnan, and Hanafi (2002), efficiency is defined as the ability of an organization to maximize its output by using certain inputs or, in other words, using the minimal input to produce a certain output. In addition, Kost and Rosenwig (1979) demonstrate three factors contributing to efficiency: The same number of inputs generates a bigger output; a smaller number of inputs generate the same output; and a bigger input generates a bigger output. The main point is that efficiency involves the management of the input, with the aim of generating the maximum output.

One common method used to measure efficiency is Data Envelopment Analysis (DEA) as proposed by Charnes, Cooper, and Rhodes (CCR) in 1978. DEA is a "data oriented" approach to evaluate the performance of an
Economic Activity Unit (EAU). DEA identifies the unit used as a reference to find the cause, and a way out, of inefficiency, which is a major advantage in managerial applications (Epstein \& Henderson, 1989).

Banks, as intermediary institutions, are required to operate efficiently. One of the degrees of global efficiency's competitiveness refers to the Global Competitiveness Index ranking. It is used by taking into account 12 indicators which are divided by 3 sub-indexes, comprising of the basic sub index, the efficiency sub index, and the innovation and sophistication sub index. Table 1 presents the performance of the ASEAN countries compared to the world rankings, which shows that the positions of the ASEAN countries, particularly those belonging to the ASEAN-5, are ranked among the top 50 in the world. The ranks of the other ASEAN countries on all the indicators are far below the ASEAN-5. The higher global competitiveness ranking of a country indicates the country's globally high standards.

Table 1. The Global Competitiveness Ranking of ASEAN countries based on the Global Competitiveness Index (GCI) in 2014-2015

\begin{tabular}{lcccccccc}
\hline \multirow{2}{*}{ Country } & \multicolumn{2}{c}{ Overall Index } & \multicolumn{2}{c}{ Basic Sub index } & \multicolumn{2}{c}{$\begin{array}{c}\text { Efficiency } \\
\text { Sub index }\end{array}$} & \multicolumn{2}{c}{$\begin{array}{c}\text { Innovation and } \\
\text { Satisfaction Sub index }\end{array}$} \\
\cline { 2 - 9 } & Ranking & Score & Ranking & Score & Ranking & Score & Ranking & Score \\
\hline Singapore & 2 & 5.65 & 1 & 6.34 & 2 & 5.68 & 11 & 5.13 \\
Malaysia & 20 & 5.16 & 23 & 5.53 & 24 & 4.95 & 17 & 4.95 \\
Thailand & 31 & 4.66 & 40 & 5.01 & 39 & 4.53 & 54 & 3.84 \\
Indonesia & 34 & 4.57 & 46 & 4.91 & 46 & 4.38 & 30 & 4.20 \\
Philippines & 52 & 4.40 & 66 & 4.63 & 58 & 4.27 & 48 & 3.90 \\
Vietnamese & 79 & 4.44 & 93 & 3.51 & 81 & 3.74 & 75 & 4.66 \\
Lao PDR & 93 & 3.91 & 98 & 4.13 & 107 & 3.58 & 80 & 3.51 \\
Cambodia & 95 & 3.89 & 103 & 4.09 & 100 & 3.65 & 116 & 3.15 \\
Myanmar & 134 & 3.24 & 132 & 4.46 & 134 & 3.11 & 139 & 2.62 \\
Brunei Darussalam & - & - & - & - & - & - & - & - \\
\hline
\end{tabular}

Source: Schwab and Sala-i-Martin (2014) 
Explanation:

Basic Sub index

1. Institution

2. Infrastructure

3. Macroeconomic Environment

4. Health and Basic Education

7. Labor Market Efficiency

8. Development of Financial Markets

9. Technological readines

10. Market size

\section{Efficiency Sub index}

5. Higher Education and Training

6. Goods and Market Efficiency

Innovation and Satisfaction

11. Business Sophistication

12.Innovation

As intermediary institutions, banks have an important role in the economic growth of a country. Banks play a role in the movement of funds through their customers' investment activities to encourage economic growth. Further, in order to prepare for economic integration under the ASEAN Economic Community, banks in ASEAN should be increasing their performance before facing the impact of competition from well managed and well capitalized banks. Table 2 shows the ranking of the banks operating in ASEAN, based on their pre-tax profits in 2014, and their position in the ASEAN rankings. Singaporean banks, namely OCBC, DBS and UOB occupy the top three positions for their pre-tax profits, as well as the top three ASEAN rankings.

According to Table 2, DBS is the best bank in ASEAN, followed by OCBC and UOB respectively. Furthermore, Maybank came in not only as the fourth ranked bank for pre-tax profits but also as the fourth ranked bank in the ASEAN rankings. Indonesian banks, BRI and Bank Mandiri were ranked in the fifth and sixth positions. BRI was more advanced than Bank Mandiri in terms of its pre-tax profit, but the ASEAN ranking of Bank Mandiri was higher than that for BRI. The last tier is dominated by Malaysian and Thai banks including CIMB, Siam Commercial Bank, and Public Bank Berhad and the final place is held by Kasikornbank.

The tight banking competition in ASEAN indicates that every country in ASEAN is required to operate efficiently. Conceptually, efficiency is closely related to inputs and outputs, dealing with how an institution is able to optimally allocate production factors (inputs) to maximize outputs. For banking, efficiency is the most important aspect for realizing healthy

Table 2. Top 10 Pre-Tax Profit in 2014

\begin{tabular}{cclcc}
\hline Rank & $\begin{array}{c}\text { ASEAN } \\
\text { Ranking }\end{array}$ & \multicolumn{1}{c}{ Bank Name } & Country & $\begin{array}{c}\text { Pre-tax Profit (US\$ } \\
\text { Miliar) }\end{array}$ \\
\hline $\mathbf{1}$ & 2 & Overseas Chinese Banking Corporation (OCBC) & Singapore & $4,053.81$ \\
$\mathbf{2}$ & 1 & DBS Bank & Singapore & $3,763.89$ \\
$\mathbf{3}$ & 3 & United Overseas Bank (UOB) & Singapore & $2,737.88$ \\
$\mathbf{4}$ & 4 & Maybank & Malaysia & $2,581.62$ \\
$\mathbf{5}$ & 12 & Bank Rakyat Indonesia (BRI) & Indonesia & $2,467.38$ \\
$\mathbf{6}$ & 9 & Bank Mandiri & Indonesia & $2,109.71$ \\
$\mathbf{7}$ & 10 & CIMB Group & Malaysia & $1,843.69$ \\
$\mathbf{8}$ & 7 & Siam Commercial Bank (SCB) & Thailand & $1,671.03$ \\
$\mathbf{9}$ & 5 & Public Bank BHD (PBB) & Malaysia & $1,669.04$ \\
$\mathbf{1 0}$ & 11 & Kasikornbank & Thailand & $1,599.01$ \\
\hline
\end{tabular}


and sustainable banking performance. Wheelock and Wilson (1995) stated that efficiency is an important criterion for a bank's operating condition, and a key indicator of a bank's success when compared with the overall banking industry.

Şahin, Y1lmaz, and Akgün (2013) assert that efficiency is one of the keys for competitiveness. However, increasing competition among banks, as a consequence of an agreement by the ASEAN Economic Community (AEC), has encouraged every bank to operate efficiently. Thus, the objective of the study is to analyze the banking efficiency levels in the ASEAN-5 countries.

\section{LITERATURE REVIEW}

\section{Banking Efficiency}

Tighter banking competition encourages banks to operate more efficiently. Increasing efficiency becomes a strategic step, since it is a strategic move carried out by the bank to survive in all conditions. Berger and Mester (1997) described that from the micro perspective; it will be difficult for an inefficient bank to maintain the required number of customers, and it is less likely to be attractive to potential new customers, due to the decreasing customer confidence in the bank. On the other hand, from the macro perspective, an efficient banking industry may affect the cost of financial intermediation and the overall stability of the financial system. This is due to the strategic role of the banking industry as the intermediary and service producer when allocating financial resources, and can ultimately increase investment and economic growth (Abidin \& Endri, 2009).

The concept of efficiency was first introduced by Farrell (1957) who proposed various concepts for efficiency, from simple cases such as the two factors of production to produce a single output, to more complex cases such as calculating the efficiency of enterprises with multiple inputs and multiple outputs. To sum up, there are two components of efficiency, consisting of technical efficiency and price or allocative efficiency. Technical efficiency measures a company's success by optimally set inputs to generate the maximum output. While allocative efficiency or price efficiency is a company's ability to use a certain proportion of its input, at a certain price, optimally. Kumbakhar and Lovell (2000) stated that technical efficiency is one of the components of overall economic efficiency. However, in order to achieve economic efficiency, a company should be technically efficient. The aim of measuring efficiency, according to Hadad, Santoso, Ilyas, and Mardanugraha (2003), is to draw an accurate frontier. The frontier can be obtained by using DEA and stochastic frontiers. The increasingly advanced era facilitates researchers in the measurement of efficiency with a variety of software that is easy to obtain. Coelli, O'Donnell, and Battese (2005) describe how to measure efficiency by using a Data Envelopment Analysis Program (DEAP). In addition, Farrell (1957) asserts that the measurement of an entity's efficiency can be seen both in terms of its input oriented and output oriented. Input-oriented measurements assume that a company uses two types of inputs, $\mathrm{x}_{1}$ and $\mathrm{x}_{2}$, to produce one type of output (y), by employing the Constant Returns to Scale (CRS) method. This CRS method assumes that, for a percentage increase in the number of inputs $\left(\mathrm{x}_{1}\right.$ and $x_{2}$ ), then the output will also increase by the same percentage. The concept of efficiency from this input-oriented approach can be described as follows in Figure 1.

Curve SS' in Figure 1 is an isoquant curve, which is a set of points of the most fully efficient firms. The point $\mathrm{P}$ is a company classified as less 


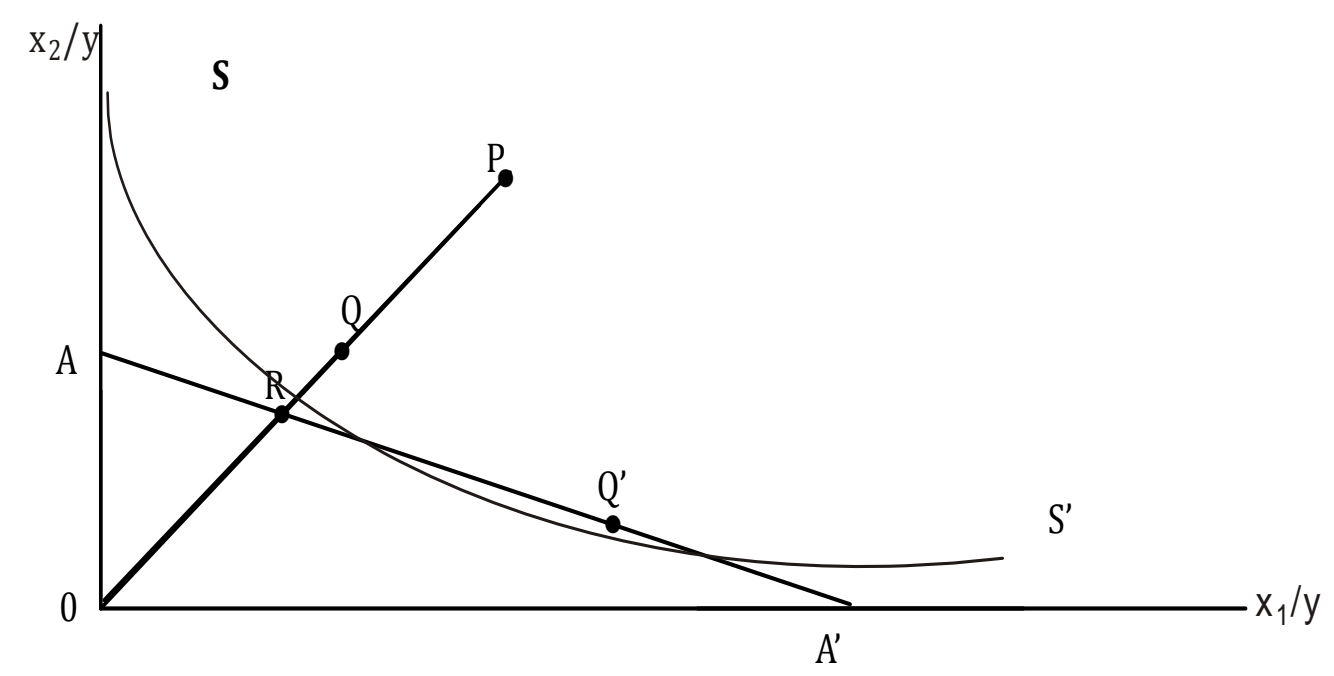

Figure 1. Input Oriented Efficiency Concept

Source: Coelli et al. (2005)

efficient, because the amount of input by company $\mathrm{P}$ is too high for the output, so that the company should reduce both its inputs, $\mathrm{x}_{1}$ and $\mathrm{x}_{2}$, to produce one unit of output. The aim of the reduction is for the company to be at the point $\mathrm{Q}$. The distance of P-Q indicates the potential for improvement to companies that are not efficient. This potential improvement deals with how much the input quantity can be reduced to produce the same quantity output. The size of the Technical Efficiency (TEi) of a company in a group of companions is generally measured by the following ratio:

$$
\mathrm{Ei}=1-\mathrm{QP} / \mathrm{OP}=0 \mathrm{Q} / 0 \mathrm{P}
$$

Thus $0-\leq \mathrm{TEi} \leq 1$. A TEi score $=1$ indicates that company $\mathrm{i}$ is technically the most efficient among its companions. The $\mathrm{AA}^{\prime}$ line is an isocost line showing the price ratio of input two to input one. The Allocative Efficiency (AEi) of company $i$ is at a point $P$, indicated by the ratio:

$$
\mathrm{AEi}=1-\mathrm{RQ} / 0 \mathrm{Q}=0 \mathrm{R} / 0 \mathrm{Q}
$$

On the other hand, the R-Q represents the reduction in production costs, which would occur if production were carried out at the technically and allocatively efficiency point for both, namely point $\mathrm{Q}$. The point $\mathrm{Q}$ is technically efficient, but inefficient allocatively. The Economic Efficiency (EEi) of a firm is a product of the Technical Efficiency (TEi) with the Allocative Efficiency (AEi), mathematically presented below:

$$
\begin{aligned}
\mathrm{EEi} & =\mathrm{TEi} \times \mathrm{AEi}=(0 \mathrm{Q} / 0 \mathrm{P}) \times(0 \mathrm{R} / 0 \mathrm{Q}) \\
& =0 \mathrm{R} / 0 \mathrm{P}
\end{aligned}
$$

Where $0 \leq \mathrm{TEi}, \mathrm{AEi}, \mathrm{EEi} \leq 1$.

In contrast to the input oriented approach, the output orientated approach answers how much the output can be increased proportionally to the same input. Inversely to the input oriented approach, the output oriented approach assumes that a company uses two types of output $\left(\mathrm{y}_{1}\right.$ and $y_{2}$ ) and one type of input ( $x$ ) and uses the constant return to scale.

Figure 2, curve ZZ' is called the production probability figure while the DD' line is an isorevenue line showing both output prices. Point $\mathrm{B}$ is a technically efficient point while point A is inefficient. The distance A-B is the degree of probable potential improvement carried out by companies at point $\mathrm{A}$ to make them technically efficient. The degree of a 
company's technical efficiency is:

$$
\mathrm{TEi}=1-\mathrm{AB} / 0 \mathrm{~B}=0 \mathrm{~A} / 0 \mathrm{~B}
$$

Whereas Allocative Efficiency (AEi) can be calculated by:

$$
\mathrm{AEi}=1-\mathrm{BC} / 0 \mathrm{C}=0 \mathrm{~B} / 0 \mathrm{C}
$$

Improvement to point $\mathrm{C}$ indicates that companies at point $\mathrm{B}$ can increase their income by producing at the technically and allocatively efficient point that is point B'. Generally, economic efficiency is a product of technical efficiency with allocative efficiency, mathematically:

$$
\begin{aligned}
\mathrm{EEi} & =\mathrm{TEi} \times \mathrm{AEi}=0 \mathrm{~A} / 0 \mathrm{~B} \times 0 \mathrm{~B} / 0 \mathrm{C} \\
& =0 \mathrm{~A} / 0 \mathrm{C}
\end{aligned}
$$

The input and output relative efficiency level requires defining frontiers showing the relatively most efficient companies of the competitors. Technical inefficiency occurs if the generated output is smaller than the input. The output level of the EAU is far above the isoquant line.

Allocative inefficiency occurs due to the wrongly proportioned input, so that price and productivity are at one frontier. EAU remains on the isoquant line but at the wrong point. Lastly, an inefficiency scale occurs if the total cost is reduced by changing the number of the EAU and the EAU is at the wrong point along the isoquant line.

\section{Previous Empirical Studies}

Previous research into relative banking efficiency has been widely undertaken, especially at the country level. However, in the context of interstate banking efficiency levels, it is still rare, especially at the level of the ASEAN countries. Several studies on banking efficiency in ASEAN countries have been done, such as those by Suhartono (2017), Wong and Deng (2016), and Sufian and Habibullah (2010). Suhartono (2017) conducted a study on the determinants of the productive efficiency of banks operating in eight ASEAN member countries. Using the economic theory approach, and especially the concept of Average Cost (AC) as a proxy for productive efficiency, he found that economies of scale should be considered when formulating industrial policy. This study also found that stronger capital conditions have a positive impact on bank efficiency.

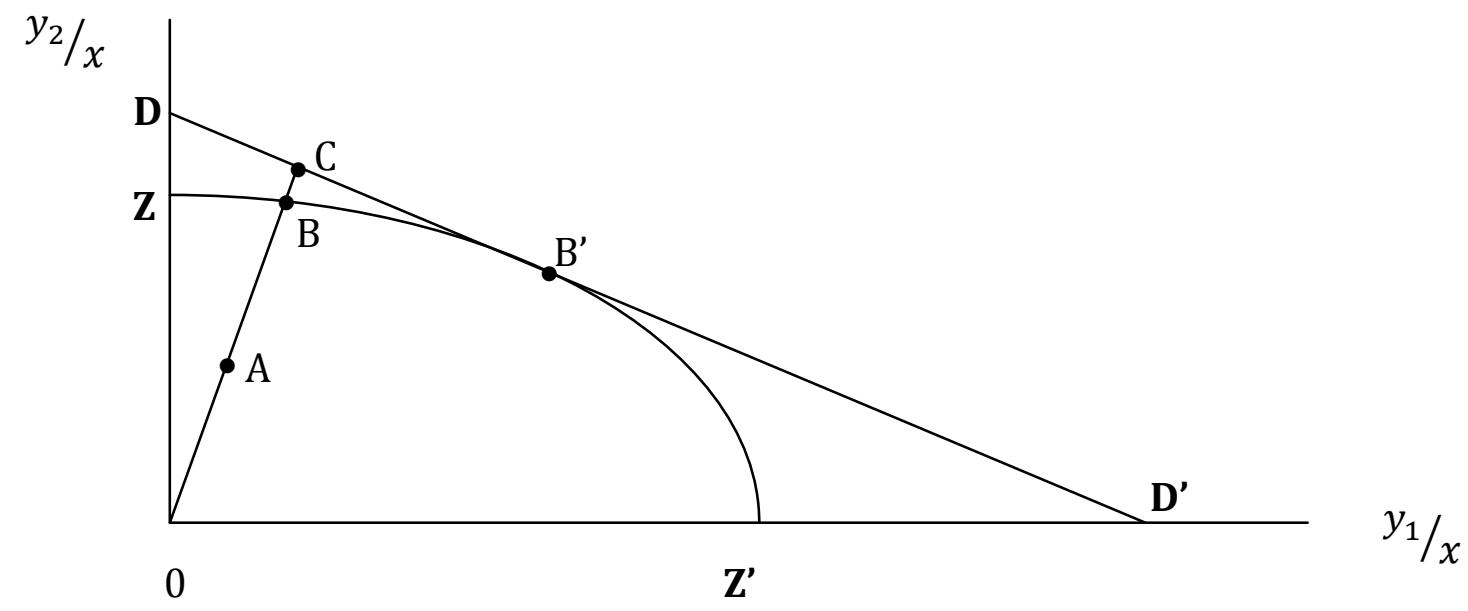

Figure 2. Output Oriented Efficiency Concept

Source: Coelli et al. (2005) 
Wong and Deng (2016) conducted a study to determine the various aspects that determine the level of banking efficiency for 39 ASEAN banks during the period from 2000 to 2010, entitled "Efficiency Analysis of Banks in ASEAN Countries", and found three important things: (1) Banking in Malaysia is more efficient than 3 other banks in ASEAN (Indonesia, the Philippines, and Thailand); (2) major banks in ASEAN have inefficient costs; and (3) government banks in the ASEAN region showed significant efficiency improvements throughout the study, this differs from the efficiency shown by non-government banks.

Sufian and Habibullah (2010) conducted research into the development of banking efficiency in Thailand using the DEA approach. The object of this research was domestic banks and foreign banks operating in Thailand during the period from 1999 to 2008. The output variables used were total deposits, fixed assets, and labor, while the input variables used were total credit, investment, and NII. The results of this empirical research indicated that the scale of the inefficiency exceeded the pure technical inefficiency in the calculation of the banks' technical efficiency in Thailand. Thailand's domestic banks should be proud that they show greater technical efficiency than the foreign banks operating there.

\section{METHOD, DATA, AND ANALYSIS}

Banks, as the sample in this study, were taken using a purposive sampling method, which was selecting the sample with certain considerations, particularly regarding the availability of data during the study. Other considerations included: (1) Are the banks domestic banks or local banks operating in each ASEAN-5 country; (2) the biggest banks with the largest total assets, based on the ratings quoted by ASIAN banking in 2012-2013; and (3) can they provide complete financial statements from 2006 to 2013 on their respective websites.

One way to determine the size of a bank is by looking at its total assets. Bigger banks usually perform well, because the greater the amount of assets owned by such a bank means its liquidity is greater too, and the velocity of money in a bank is good. In addition, Berger and Mester (1997) stated that the selection of good banks is because the financial market is predicted to be more global

Table 2. Sample Banks

\begin{tabular}{clc}
\hline No & \multicolumn{1}{c}{ Bank Name } & $\begin{array}{c}\text { Country of } \\
\text { Origin }\end{array}$ \\
\hline 1 & Bank Central Asia & \\
2 & Bank Danamon & Indonesia \\
3 & Bank Negara Indonesia & \\
4 & Bank Mandiri & \\
5 & Alliance Bank Malayan Berhad & \\
6 & Hong Leong Bank & Malaysia \\
7 & Public Bank Berhad & \\
8 & RHB Bank Berhad & \\
9 & BDO Unibank & Philippines \\
10 & Philippines Bank of the Islands & \\
11 & Philippines National Bank & \\
12 & DBS Bank & Singapore \\
13 & OCBC Bank & \\
14 & UOB Bank & \\
15 & Bangkok Bank & Thailand \\
16 & Kasikornbank & \\
17 & Siam Commercial Bank & \\
\hline Source: Compiled by authors &
\end{tabular}

The technical efficiency of banking is related to the management of a number of inputs and outputs. This study will use the non-parametric approach of Data Envelopment Analysis (DEA) because the DEA concept does not require assumptions about the form of the mathematical functions. The required variables to calculate the score efficiently are the input and output variables. The intermediary approach was used to choose the input-output variables. The input variables used were employees' benefits, fixed 
assets and deposits, while, the output variables were total income and loans. The initial step of the analysis was to identify the EAU to be observed and the input-output variables used, followed by calculating the efficiency of every EAU to further analyze every efficiency score studied. The relative efficiency of an EAU is formulated as follows:

$\begin{gathered}\text { Efficiency of } \\ \text { economic activity unit }\end{gathered}=\frac{\text { Total weighted output }}{\text { Total weighted input }}$

An efficiency score ranges from $0-1$ and is not higher than $1(\leq 1)$. If an EAU obtains 1 for its efficiency score, it means that the EAU has technically reached its maximum efficiency and if it is $<1$, it means that the EAU is inefficient. During this process, the relative efficiency calculation using the DEA method employed MaxDEA software.

The CCR-output oriented model was chosen because it assumes that the EAU operates on an optimum scale, in addition to the current conditions in which the ASEAN countries will experience a liberalization of their financial services sectors. Liberalization is synonymous with deregulation, which is the reduction of all obstacles by the government to smooth the economy of the state. The reason for choosing an output orientation was because it is assumed that the banks in the ASEAN-5 are very competitive, and this would encourage the banks to compete to get the best ranking position in ASEAN.

\section{RESULT AND DISCUSSION}

The core of the relative efficiency of the EAU is to calculate or determine the amount of weighted weight of each output and inputs used. The calculation results in a score for the relative efficiency, ranging between $0-1$ which indicates that, if the relative efficiency score is closer to one, then the EAU's efficiency is relatively high.
If it is closer to zero, the EAU's efficiency is relatively low. The reason is that relative efficiency, from the concept of DEA (Data Envelopment Analysis), is the result of the total weighted output divided by the total weighted input, which is 1 or $100 \%$. The ratio cannot generate results higher than 1 or $\leq 1$.

In this study, there were 17 EAUs used as samples, comprising of the representative banks in accordance with the sample criteria in each of the countries being studied. Score identification for each bank used MaxDEA. Calculations using the Constant Return to Scale (CRS) approach are beneficial since they can see any slack in the input and output variables. Slack in the input indicates how much it causes inefficiency, which should be deducted proportionally, so that each EAU can achieve its efficiency level. Slack in the output shows the amount of output that must be increased proportionally so that the efficiency of the unit's economic activities can be improved to make it the most efficient EAU. A further explanation about the efficiency of the banks' performance in each ASEAN-5 country is presented in Table 3 below.

Table 3 shows that in the period from 2006 to 2013, there were only two banks, Bank Mandiri and Bank Danamon that consistently maintained their efficiency levels at $100 \%$. Meanwhile, the efficiency scores of Bank Negara Indonesia tended to fluctuate and its relative average efficiency score was $92.55 \%$. Between 2006 and 2011, Bank Central Asia's (BCA) efficiency score was relatively high, reaching a maximum of $100 \%$, but in 20122013, the score tended to decrease. During the eight years of the study period, the average efficiency score for BCA is relatively higher than that for Bank Negara Indonesia, whose average is the lowest. 
Table 3. Average Indonesian Banking Efficiency Score 2006-2013

\begin{tabular}{cccccc}
\hline \multirow{2}{*}{ Year } & \multicolumn{4}{c}{ Economic Activity Unit (EAU) } & \\
\cline { 2 - 5 } & $\begin{array}{c}\text { Bank Central } \\
\text { Asia }\end{array}$ & Bank Mandiri & $\begin{array}{c}\text { Bank Negara } \\
\text { Indonesia }\end{array}$ & $\begin{array}{c}\text { Bank } \\
\text { Danamon }\end{array}$ & \\
\hline 2006 & $100 \%$ & $100 \%$ & $85.09 \%$ & $100 \%$ & $96.27 \%$ \\
2007 & $100 \%$ & $100 \%$ & $90.34 \%$ & $100 \%$ & $97.58 \%$ \\
2008 & $100 \%$ & $100 \%$ & $100 \%$ & $100 \%$ & $100 \%$ \\
2009 & $100 \%$ & $100 \%$ & $100 \%$ & $100 \%$ & $100 \%$ \\
2010 & $100 \%$ & $100 \%$ & $100 \%$ & $100 \%$ & $100 \%$ \\
2011 & $100 \%$ & $100 \%$ & $87.94 \%$ & $100 \%$ & $96.98 \%$ \\
2012 & $89.16 \%$ & $100 \%$ & $89.75 \%$ & $100 \%$ & $94.73 \%$ \\
2013 & $79.47 \%$ & $100 \%$ & $87.26 \%$ & $100 \%$ & $91.68 \%$ \\
\hline Average Efficiency Score & $96.08 \%$ & $100 \%$ & $92.55 \%$ & $100 \%$ & \\
\hline
\end{tabular}

Source: Secondary Data, analyzed

The average scores of the relative efficiency of Bank Central Asia and Bank Negara Indonesia are still below those for Bank Mandiri and Bank Danamon. BCA's relative efficiency decreased by $10.84 \%$ in 2012 , indicating that there were a number of outputs that should have been increased by utilizing the existing input for $10.84 \%$ of the number produced. Similarly, Bank Negara Indonesia tended to fluctuate because BNI was quite optimal in using its inputs and outputs, so that its efficiency score was lower than $100 \%$. The variables that explain the cause of the inefficiency of the banks that experienced a relative efficiency lower than $100 \%$ in Indonesia are presented below.
Table 4 shows that the average score for Malaysia's banking efficiency during the study period was relatively high. Particularly during 2006 and 2007, all the banks show the maximum relative efficiency level of $100 \%$. This indicates that banks in Malaysia, in those years, were able to manage their inputs and outputs optimally. Public Bank Berhad showed a consistent efficiency of 100\% between 2006 and 2013 . Alliance Bank Malaysia Berhad (ABMB) also showed good performance, as demonstrated by the high level of its relative efficiency, followed by RHB Bank Berhad which was very consistent from 2006 to 2008, although it decreased during the period from 2010 to 2013. Hong Leong Bank

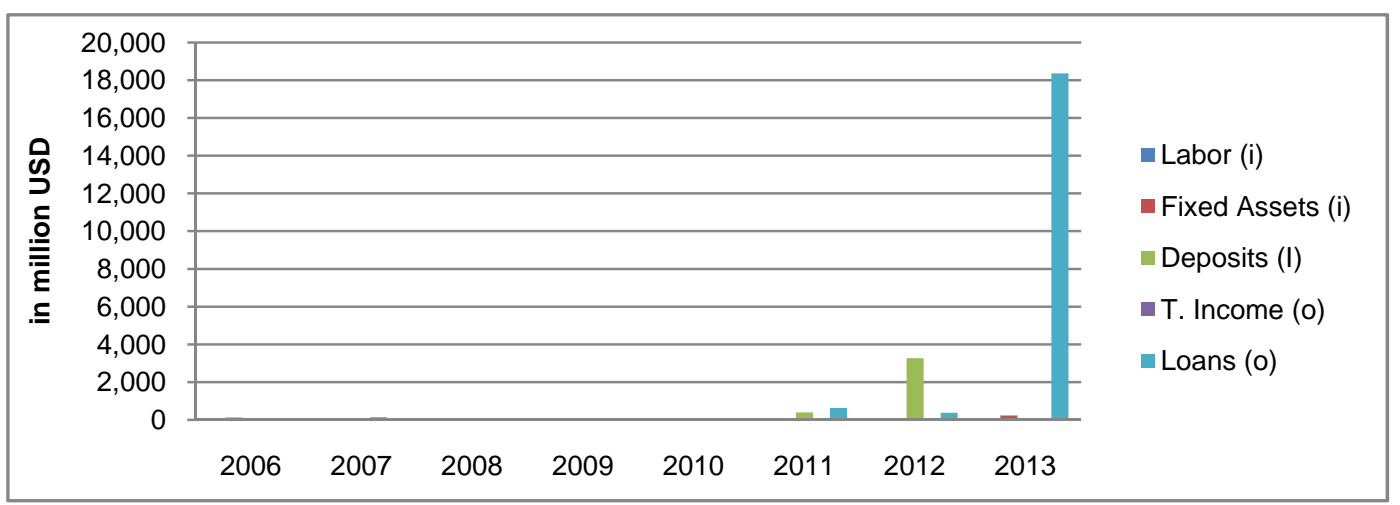

Figure 3: Input Slack and Output Slack for Indonesian Banking

Source: Secondary Data, analyzed 
Table 4. Malaysian Banking Average Efficiency Score 2006 - 2013

\begin{tabular}{cccccc}
\hline \multirow{2}{*}{ Year } & \multicolumn{5}{c}{ Economic Activity Unit (EAU) } \\
\cline { 2 - 5 } & $\begin{array}{c}\text { Alliance Bank Malaysia } \\
\text { Berhad (ABMB) }\end{array}$ & $\begin{array}{c}\text { Hong Leong } \\
\text { Bank (HLB) }\end{array}$ & $\begin{array}{c}\text { Public Bank } \\
\text { Berhad (PBB) }\end{array}$ & $\begin{array}{c}\text { RHB Bank } \\
\text { Berhad }\end{array}$ & \\
\hline 2006 & $100 \%$ & $100 \%$ & $100 \%$ & $100 \%$ & $100.00 \%$ \\
2007 & $100 \%$ & $100 \%$ & $100 \%$ & $100 \%$ & $100.00 \%$ \\
2008 & $100 \%$ & $96.46 \%$ & $100 \%$ & $100 \%$ & $99.12 \%$ \\
2009 & $100 \%$ & $100 \%$ & $100 \%$ & $100 \%$ & $100.00 \%$ \\
2010 & $97.35 \%$ & $93.78 \%$ & $100 \%$ & $99.33 \%$ & $97.61 \%$ \\
2011 & $98.31 \%$ & $95.28 \%$ & $100 \%$ & $93.75 \%$ & $96.83 \%$ \\
2012 & $100 \%$ & $89.10 \%$ & $100 \%$ & $91.24 \%$ & $95.09 \%$ \\
2013 & $93.18 \%$ & $83.68 \%$ & $100 \%$ & $96.21 \%$ & $93.27 \%$ \\
\hline Average & $99 \%$ & $95 \%$ & $100 \%$ & $98 \%$ & \\
Efficiency Score & & & & & \\
\hline
\end{tabular}

Source: Secondary Data, analyzed

(HLB) had the most volatile efficiency score but unfortunately, in 2011-2013, its relative efficiency score declined. Inefficiency also occurred in ABMB, HLB and RHB banks in those years, because of the less than optimal management of the inputs and outputs. Below is a picture of the average input slack and output slack in the banks which have a relative efficiency score below $100 \%$.

During the study period, banking in the Philippines showed a good performance (see
Table 5). The average scores for banking efficiency in the Philippines between 2006 and 2013 were relatively high. BDO and BPI can be regarded as the most efficient banks because their relative efficiency scores were consistently $100 \%$ from 2006 to 2013. The Philippine National Bank (PNB) was relatively less efficient, because its efficiency score was quite volatile. However, the bank was able to achieve a relatively high efficiency score, close to $100 \%$ over the period from 2006 to 2013.

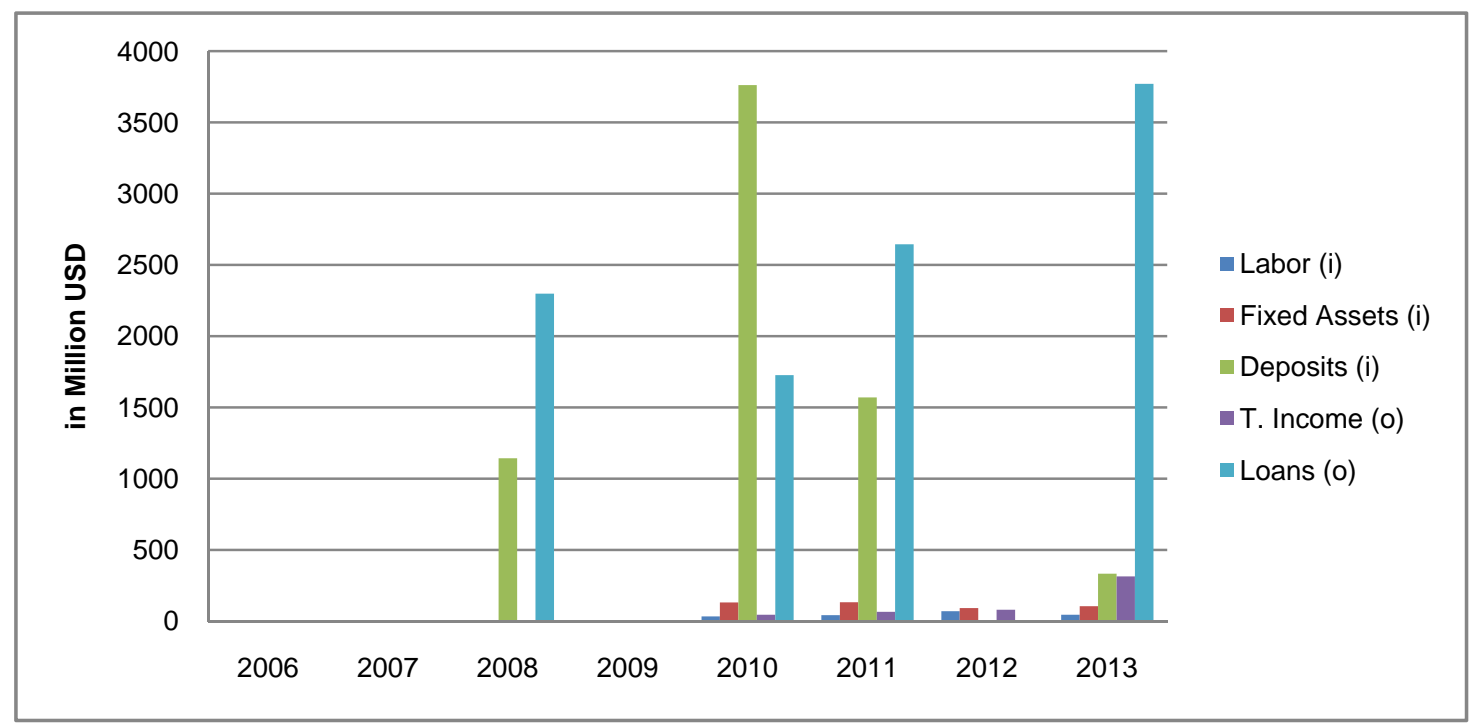

Figure 4: Input slack and Output slack for Malaysian Banking Source Secondary Data, analyzed 
Table 5. Average Efficiency Score of Philippines Banking 2006-2013

\begin{tabular}{ccccc}
\hline \multirow{2}{*}{ Year } & \multicolumn{3}{c}{ Economic Activity Unit (EAU) } \\
\cline { 2 - 4 } & $\begin{array}{c}\text { BDO } \\
\text { Unibank }\end{array}$ & $\begin{array}{c}\text { Bank of the Philippines } \\
\text { Islands (BPI) }\end{array}$ & $\begin{array}{c}\text { Philippines National } \\
\text { Bank (PNB) }\end{array}$ & \\
\hline 2006 & $100 \%$ & $100 \%$ & $99.15 \%$ & $99.72 \%$ \\
2007 & $100 \%$ & $100 \%$ & $93.70 \%$ & $97.90 \%$ \\
2008 & $100 \%$ & $100 \%$ & $94.72 \%$ & $98.24 \%$ \\
2009 & $100 \%$ & $100 \%$ & $100 \%$ & $100.00 \%$ \\
2010 & $100 \%$ & $100 \%$ & $100 \%$ & $100.00 \%$ \\
2011 & $100 \%$ & $100 \%$ & $100 \%$ & $100.00 \%$ \\
2012 & $100 \%$ & $100 \%$ & $100 \%$ & $100.00 \%$ \\
2013 & $100 \%$ & $100 \%$ & $97.92 \%$ & $99.31 \%$ \\
\hline Average Efficiency Score & $100 \%$ & $100 \%$ & $98.19 \%$ & \\
\hline
\end{tabular}

Source: Secondary Data, analyzed

BDO Unibank is a universal bank, which has the most comprehensive services in the Philippines. Some of its creative and innovative products are loans (corporate, middle market, SME, and consumer), deposit-taking, foreign exchange, brokering, and so forth. It has 860 branches and over 2,500 ATMs, making it the biggest bank in the Philippines in terms of its resources, capital, customer loans, total deposits, and asset management. These are the key strengths of BDO which enable it to run a successful business, and everything is based on customer satisfaction.

The Bank of the Philippines Islands (BPI) is a bank whose focus is on expanding its core business, which is lending and deposit-taking in the country. This allows the bank to expand and grow gradually from year to year. In addition, BPI's major market is the people living in rural areas. Furthermore, BPI has been using a mobile phone accounts system since 2011. The strategies undertaken by BPI have allowed it to serve around seven million customers in the Philippines. BPI's total assets, loans, deposits, and its substantial capital allow it to regularly be ranked in the top five banks every year, in terms of the four indicators in the Philippines (The Philippines Banking System, 2006-2013). It indicates that BPI consistently manages its existing resources optimally. On the other hand, the Philippines National Bank was only able to achieve technical efficiency scores between 2009 and 2012. In 2013, a 1.08\% decrease in efficiency occurred repeatedly. The factors causing inefficiency in the selected Philippines banks during the study period are shown in Figure 5.

Singapore liberalized its banking sector in 2001 , with the aim of making the big local banks consolidate with smaller local banks, so they could compete with the foreign banks that were now free to enter the country. This policy left Singapore with only three local banks, but these banks are very good in terms of their assets, capital, loans, and deposits. The three banks are not only able to expand in the country, but also into most of the countries in Asia.The most efficient bank in Singapore is DBS Bank, as it maintained a $100 \%$ efficiency score in each period of our study. DBS bank is able to operate consistently in the fluctuating economic conditions in Singapore. OCBC is almost the same as DBS Bank but, in 2013, if OCBC improved its inputs and outputs by $1.6 \%$, then it would have reached its maximum efficiency, as DBS Bank and UOB did. Furthermore, UOB's 


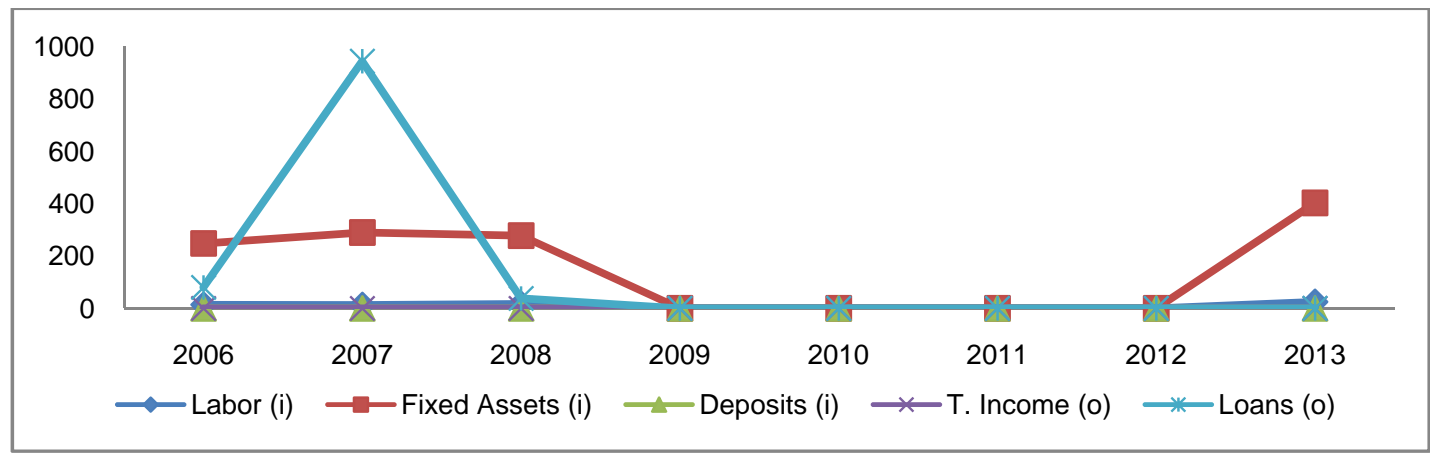

Figure 5. Input slack and Output slack for Philippines Banking Source: Secondary Data, analyzed

Table 6. Average Efficiency Score of Singaporean Banking 2006-2013

\begin{tabular}{ccccc}
\hline \multirow{2}{*}{ Year } & \multicolumn{2}{c}{ Economic Activity Unit (EAU) } & \multirow{2}{*}{ Average } \\
\cline { 2 - 4 } & DBS & OCBC & UOB & $100 \%$ \\
2006 & $100 \%$ & $100 \%$ & $100 \%$ & $100 \%$ \\
2008 & $100 \%$ & $100 \%$ & $100 \%$ & $100 \%$ \\
2009 & $100 \%$ & $100 \%$ & $100 \%$ & $100 \%$ \\
2010 & $100 \%$ & $100 \%$ & $100 \%$ & $100 \%$ \\
2011 & $100 \%$ & $100 \%$ & $97.22 \%$ & $99.07 \%$ \\
2012 & $100 \%$ & $100 \%$ & $97.45 \%$ & $99.15 \%$ \\
2013 & $100 \%$ & $100 \%$ & $100 \%$ & $99.47 \%$ \\
\hline Average Efficiency Score & $100 \%$ & $98.40 \%$ & $99.33 \%$ & \\
\hline
\end{tabular}

Source: Secondary Data, analyzed

performance between 2006 and 2010 was correspondingly excellent, since its relative efficiency score reached 100\%. In 2011-2012, UOB's efficiency score decreased, but it can be said that it was still relatively high. In a similar manner to OCBC in 2011 and 2012, UOB could have achieved the maximum relative efficiency score if it had properly managed its inputs and outputs for $2.78 \%$ and $2.55 \%$ of the current efficiency score. Overall, the efficiency level of Singaporean banking is relatively high.

DBS is the largest bank in Singapore and Southeast Asia, since it has millions of customers and each operational activity they perform always receives awards from the various survey agencies, one of them for being the safest bank, according to Global Finance. A wide range of facilities such as training and development as well as rewards, are provided to DBS's human resources, to encourage them to form a high performing and qualified organization. In addition, DBS has 250 branches across 17 markets in Asia, which increases people's satisfaction with DBS so that they are interested in saving and borrowing with it, as well as taking advantage of the other facilities it offers. The banks' non-performing loans are always below $(<) 5 \%$, and its loan to deposit ratio consistently averages about $75 \%$ (from the financial statements of DBS bank), which all go to make DBS the most efficient bank in Singapore. The variables that caused OCBC and UOB's efficiency scores to drop below $100 \%$ in the specific years are presented below. 


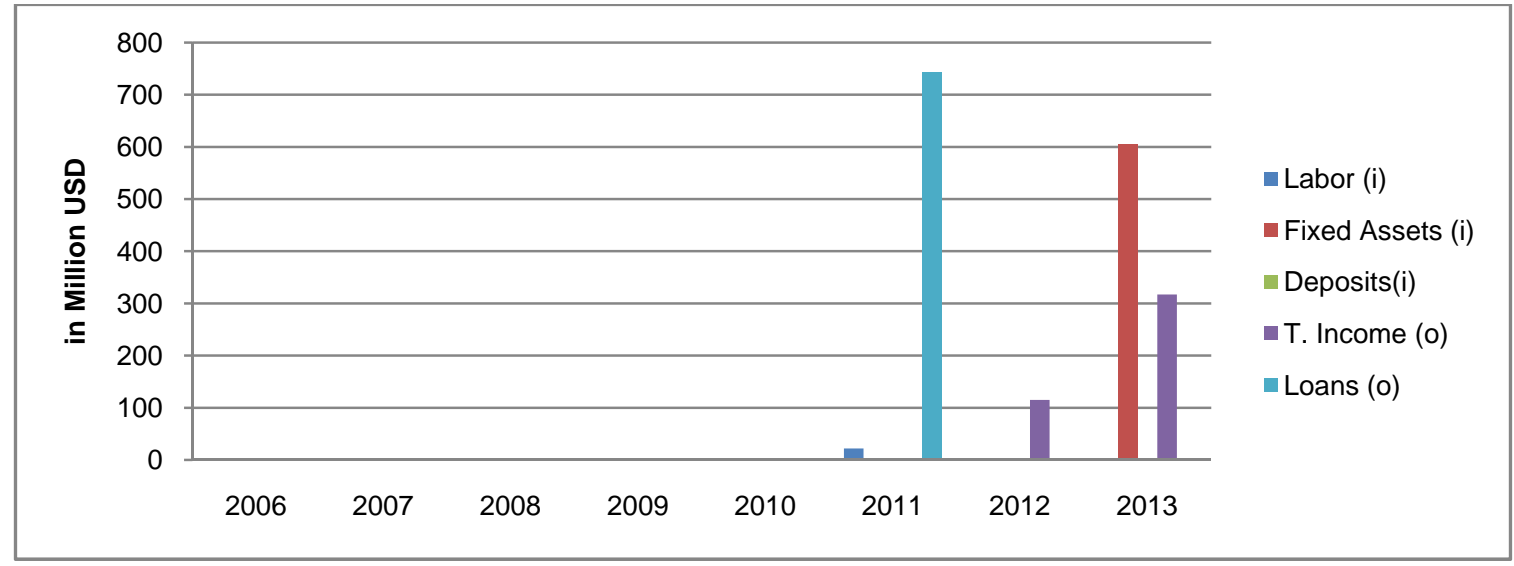

Figure 6. Input slack and Output slack for Singaporean Banking Source: Secondary Data, analyzed

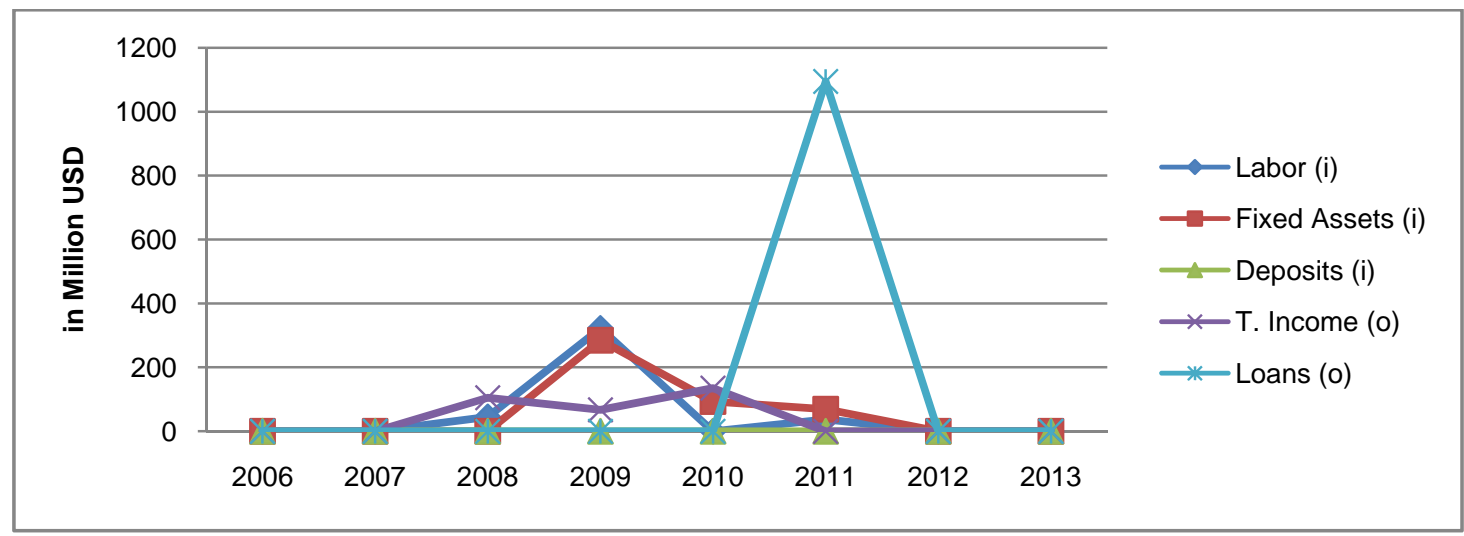

Figure 7. Input slack and Output slack for Thailand Banking Source: Secondary Data, analyzed

According to Table 7, the performance of the banks in Thailand has not been consistent during the period from 2006 to 2013. Nonetheless, the average scores for the relative efficiency of banks in Thailand were relatively high. Bangkok Bank's average relative efficiency score is the highest in Thailand and only in 2010 was its relative efficiency score under 100\%. Kasikornbank, the fourth-biggest bank by assets in Thailand, is seen to be efficient only in 20062007, but then in 2008, its efficiency score decreased to $98.61 \%$. Siam Commercial Bank (SCB), the second biggest bank in Thailand, was inefficient only in 2008 with a score of $94.03 \%$.

\section{Banking Efficiency in Asean-5}

The results from the DEA calculation in this study using a Constant Return to Scale (CRS) approach are output oriented. Banks are said to be efficient if they have efficiency scores of $100 \%$, while banks that have efficiency scores below $100 \%$ are said to be inefficient. Table 8 shows the results of the banking efficiency scores for each country in the ASEAN-5. DEA calculation results for the banks in Indonesia show that in the period from 2006 to 2013, there were only two banks that consistently maintained the maximum level of efficiency; only efficient banks can perform their intermediary functions properly. 
Table 7. Thailand Banking Average Efficiency Score 2006-2013

\begin{tabular}{ccccc}
\hline \multirow{2}{*}{ Year } & \multicolumn{3}{c}{ Economic Activity Unit (EAU) } & \multirow{2}{*}{ Average } \\
\cline { 2 - 4 } & Bangkok Bank & Kasikornbank & Siam Commercial Bank & \\
\hline 2006 & $100 \%$ & $100 \%$ & $100 \%$ & $100 \%$ \\
2007 & $100 \%$ & $100 \%$ & $100 \%$ & $100 \%$ \\
2008 & $100 \%$ & $95.66 \%$ & $94.03 \%$ & $96.56 \%$ \\
2009 & $100 \%$ & $99.24 \%$ & $100 \%$ & $99.75 \%$ \\
2010 & $98.61 \%$ & $100 \%$ & $100 \%$ & $99.54 \%$ \\
2011 & $100 \%$ & $91.90 \%$ & $100 \%$ & $97.30 \%$ \\
2012 & $100 \%$ & $100 \%$ & $100 \%$ & $100 \%$ \\
2013 & $100 \%$ & $100 \%$ & $100 \%$ & $100 \%$ \\
\hline Average Efficiency Score & $99.83 \%$ & $98.35 \%$ & $99.25 \%$ & \\
\hline Source: Secondary Data, analyzed & & & &
\end{tabular}

Table 8. Banking Efficiency Scores in ASEAN-5

\begin{tabular}{lcccccccc}
\hline DESCRIPTION & $\mathbf{2 0 0 6}$ & $\mathbf{2 0 0 7}$ & $\mathbf{2 0 0 8}$ & $\mathbf{2 0 0 9}$ & $\mathbf{2 0 1 0}$ & $\mathbf{2 0 1 1}$ & $\mathbf{2 0 1 2}$ & $\mathbf{2 0 1 3}$ \\
\hline INDONESIA & & & & & & & & \\
Number of EAU & 4 & 4 & 4 & 4 & 4 & 4 & 4 & 4 \\
Efficient EAU & 3 & 3 & 4 & 4 & 4 & 3 & 2 & 2 \\
Average Score & $96.27 \%$ & $97.58 \%$ & $100 \%$ & $100 \%$ & $100 \%$ & $96.98 \%$ & $94.37 \%$ & $91.68 \%$ \\
MALAYSIA & & & & & & & & \\
$\quad$ Number of EAU & 4 & 4 & 4 & 4 & 4 & 4 & 4 & 4 \\
Efficient EAU & 4 & 4 & 3 & 4 & 1 & 1 & 2 & 1 \\
Average Score & $100 \%$ & $100 \%$ & $99.12 \%$ & $100 \%$ & $97.61 \%$ & $96.83 \%$ & $95.09 \%$ & $93.27 \%$ \\
PHILIPPINES & & & & & & & & \\
Number of EAU & 3 & 3 & 3 & 3 & 3 & 3 & 3 & 3 \\
Efficient EAU & 2 & 2 & 2 & 3 & 3 & 3 & 3 & 2 \\
Average Score & $99.72 \%$ & $97.90 \%$ & $98.24 \%$ & $100 \%$ & $100 \%$ & $100 \%$ & $100 \%$ & $99.31 \%$ \\
SINGAPORE & & & & & & & & \\
Number of EAU & 3 & 3 & 3 & 3 & 3 & 3 & 3 & 3 \\
Efficient EAU & 3 & 3 & 3 & 3 & 3 & 2 & 2 & 2 \\
Average Score & $100 \%$ & $100 \%$ & $100 \%$ & $100 \%$ & $100 \%$ & $99.07 \%$ & $99.15 \%$ & $99.47 \%$ \\
THAILAND & & & & & & & & \\
Number of EAU & 3 & 3 & 3 & 3 & 3 & 3 & 3 & 3 \\
Efficient EAU & 3 & 3 & 1 & 2 & 1 & 2 & 3 & 3 \\
Average Score & $100 \%$ & $100 \%$ & $96.56 \%$ & $99.75 \%$ & $99.54 \%$ & $97.30 \%$ & $100 \%$ & $100 \%$ \\
\hline Source: Secondary Data & & & & & & & &
\end{tabular}

Source: Secondary Data, analyzed

The efficiency level of Malaysian banks shows that only one bank always achieved technical efficiency. Bank Negara Malaysia issued a prudential regulation, where banks throughout Malaysia were expected to improve their performance. Regulations made by Bank Negara Malaysia caused several banks in Malaysia to be too cautious when lending; causing the efficiency scores of these banks to remain below the maximum score, because of the pessimistic credit channel.
For the banking sector in the Philippines, from the three banks used as samples, two banks have always demonstrated consistency in maintaining their efficiency score of $100 \%$. This indicates that these banks can maintain their position as the best banks in the Philippines in terms of their total assets, loans, the amount of deposits and capital. A different condition is shown by the banks in Singapore, which have excellent scores. The Loans to Deposits ration (LDR) and Non Performing Loans (NPL) of the 
three banks in Singapore showed very good scores, which makes these banks not only the best banks in Singapore, but also in Southeast Asia and even Asia as a whole. Lastly, the efficiency of banking in Thailand showed fluctuations in its efficiency achievement. The best efficiency score for a bank in Thailand was $100 \%$. The average lowest score was $96.56 \%$, in 2008.

The efficiency measurement using the DEA approach has several advantages that are unavailable with other approaches. First, the DEA analysis is able to find the cause of inefficiency for each Economic Activity Unit (EAU); in this case, the banks studied that have a relative efficiency score below $100 \%$. The next advantage of DEA is it produces information about the condition of the input and output variables, and what needs to be improved, so that the banks studied can achieve their technical efficiency.

Figure 8 shows the efficiency achievement of the input/output variables of banks in the ASEAN-5. Differences in the economic development of the various countries occurred between 2006 and 2009 (first period) and 2010 to 2013 (second period). Indonesia showed good economic growth in the first period, however, the problem of rising fuel prices along with high inflation resulted in increased reference interest rates, which affected the banks' operations in channeling credit. The tendency of achieving efficiency by Indonesian banks in the first period increased, while in the second period, the achieved efficiency of input/output banking in Indonesia decreased. Indonesia's economy in the second period was quite volatile because of the falling value of the currency and fluctuations in fuel prices.

Similarly, in Malaysia, there was an increasing trend in the first period while the second period showed a declining trend. In 2006, the total income and employees' benefits were the most dominant variables contributing to the efficiency scores of the Malaysian banks, while the other variables were lower than $(<) \quad 15 \%$. Their total income increased from 2006 to 2007 by $4.46 \%$, which was also the increase in their efficiency scores from 2006 to 2007. In 2008, labor and the total income variables were the most dominant variables influencing the efficiency level. In contrast to the 2009-2010 and 2012-2013 periods, the contribution to input/output efficiency made by deposits, loans and that from total income were even at $25 \%$ each. In 2011, the contribution of fixed assets equaled $0 \%$, indicating that it did not contribute to the efficiency scores. The most dominant variable in that year was deposits with $36.82 \%$.

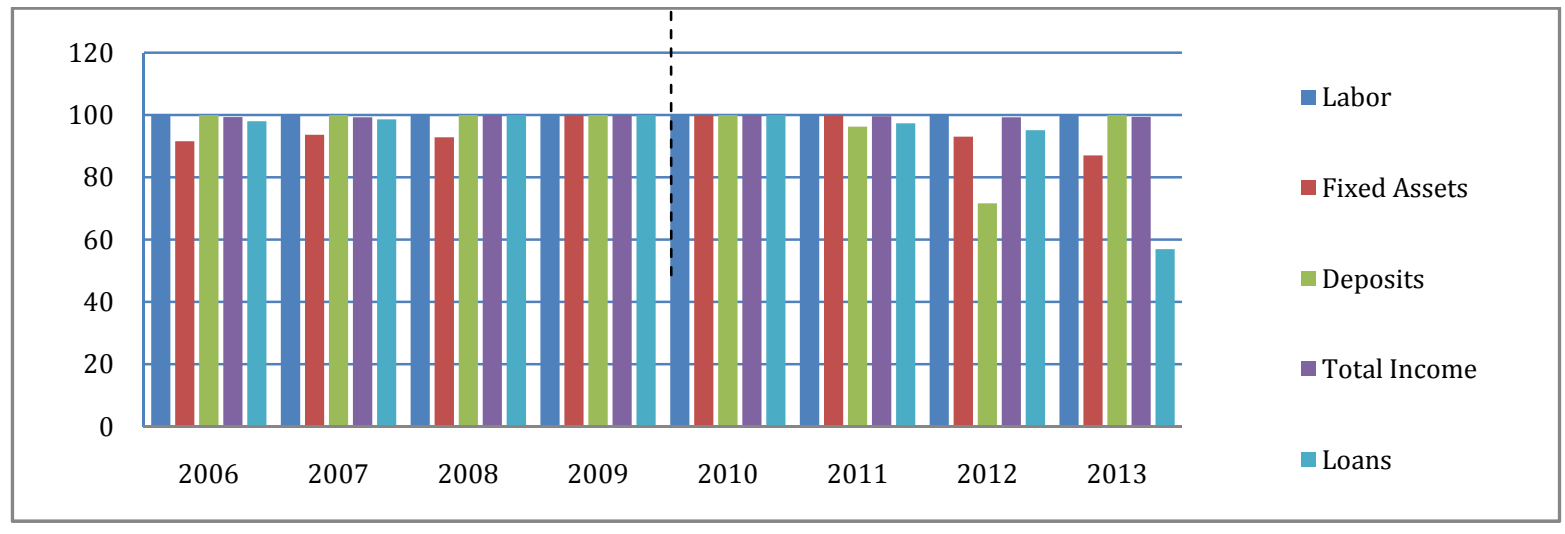

Figure 8. Efficiency Achievementof Input/Output Variables for Indonesian Banking Source: Secondary Data, analyzed 


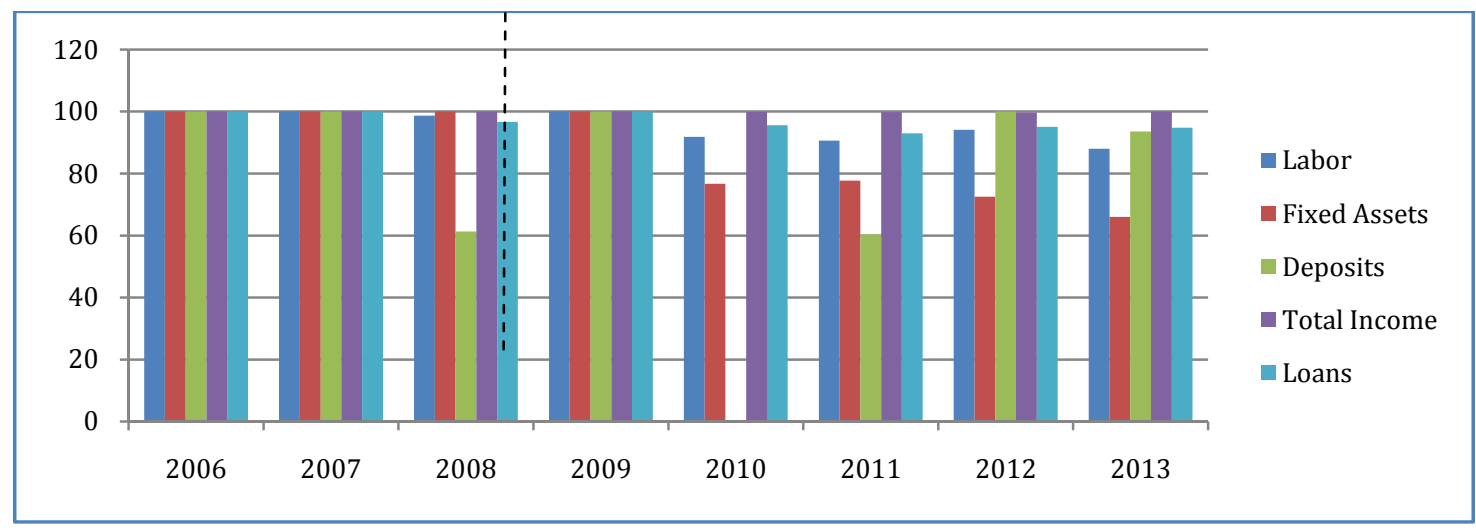

Figure 9. Efficiency Achievement of Input/Output Variables for Malaysian Banking Source: Secondary Data, analyzed

The efficiency achievement of banks in the Philippines showed a declining tendency for their inputs/outputs in the first period whereas in the second period it tended to increase. The Philippines, in the first period, experienced such macroeconomic problems as high inflation, due to rising oil prices, which certainly influenced the banks operations and the profits they could generate. In contrast, during second period, economic growth in the Philippines was stable, which allowed the banks to run properly. Banks in the Philippines showed excellent efficiency achievements in their inputs/outputs for all the variables, showing maximum figures. The efficiency achievement supported the inflation rate.

The efficiency achievements of the Singaporean banks between 2006 and 2009 were respectively $1 \%, 2.1 \%, 6.5 \%$ and $0.6 \%$.
Singapore's success in the first period was because of the synchronization of its fiscal, monetary and structural policies. However, in the second period, the global economic recovery affected the economy of Singapore. Manufacturing production was hampered by the fall in export demand, which led to the disruption of banking performance in Singapore.

During the first period, banking in Thailand showed a declining tendency in its efficiency achievement. However, in the second period it tended to increase. Inflation, due to rising world oil prices in the first period, lead to a rise in interest rates by the Bank of Thailand. In the second period, banking in Thailand showed an increase despite an economic slowdown due to political tensions. Thus, the banks are still running well despite the unfavorable economic situation.

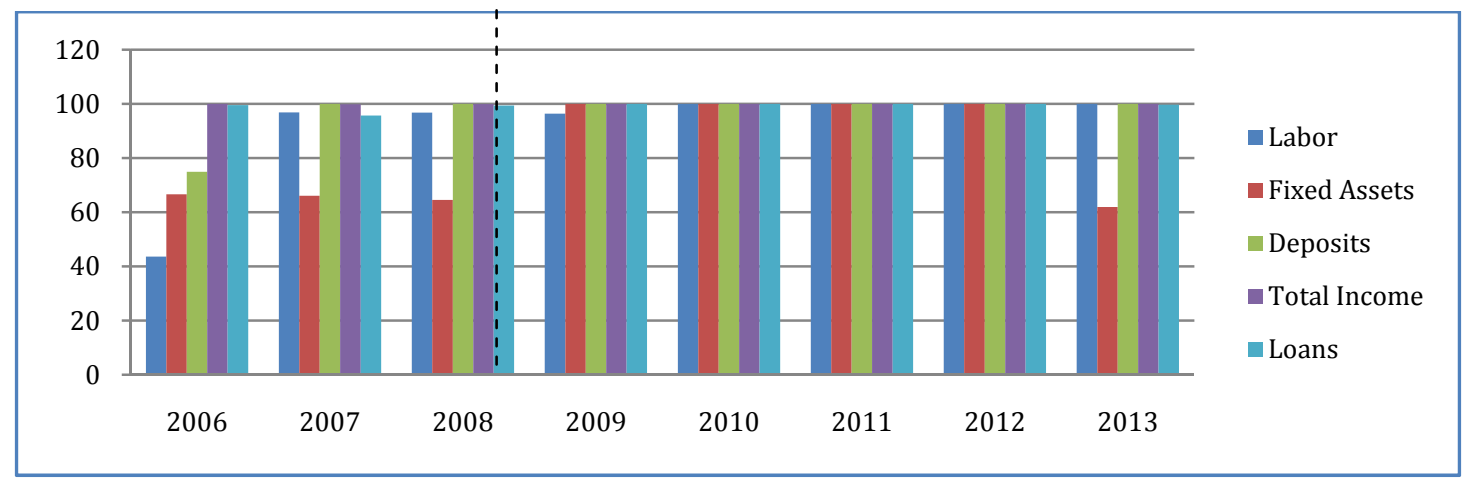

Figure 10. Efficiency Achievement of Input/Output Variables for Philippines Banking Source: Secondary Data, analyzed 


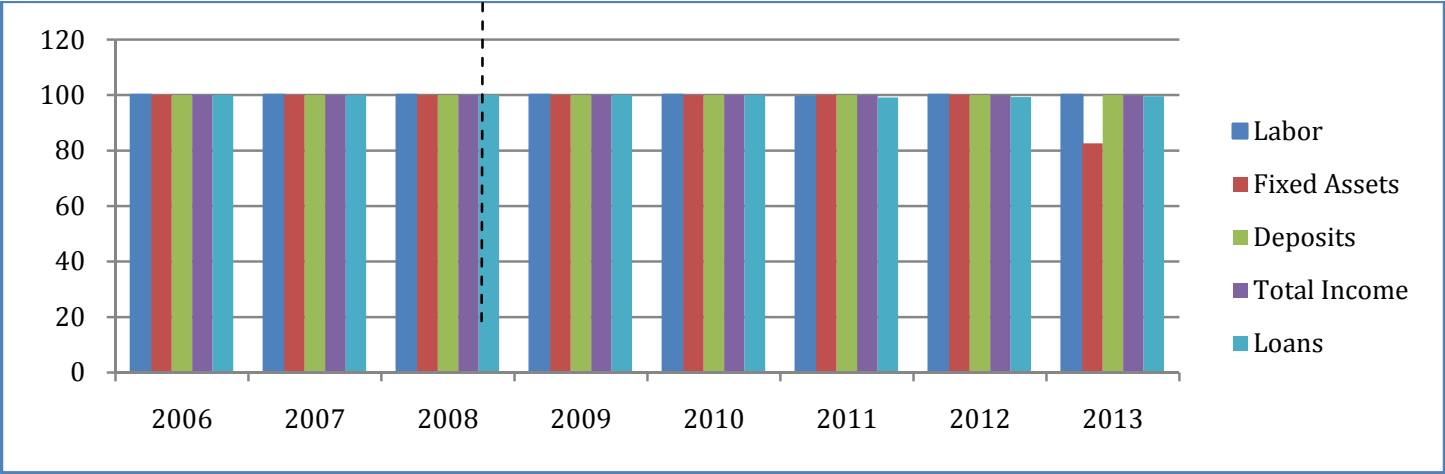

Figure 11. Efficiency Achievement of Input/Output Variables for Singaporean Banking Source: Secondary data, analyzed

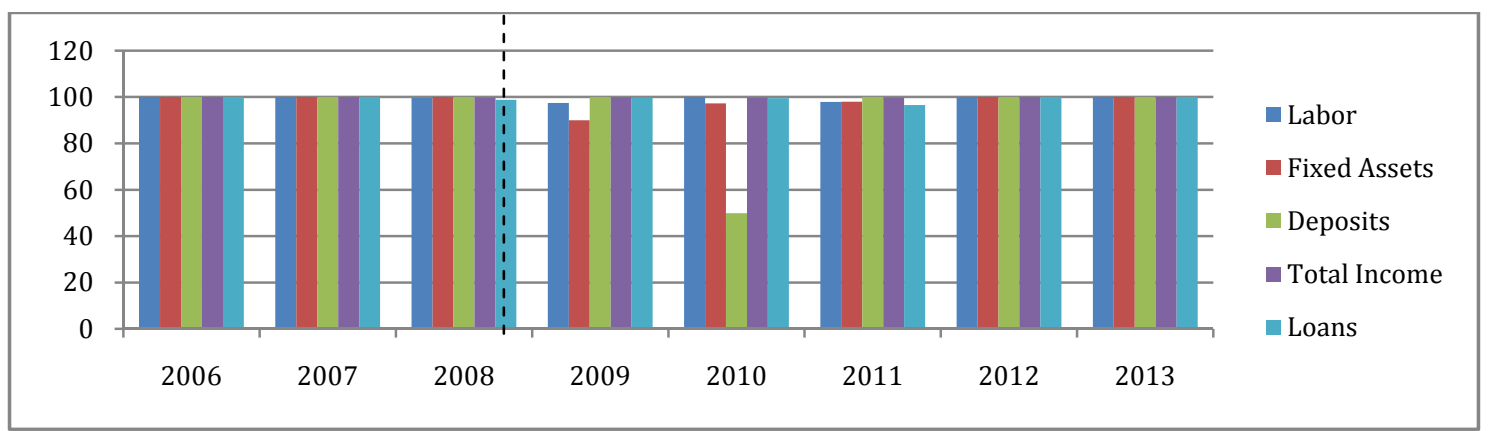

Figure 12. Efficiency Achievement of Input/Output Variables for Thailand Banking Source: Secondary data, analyzed

\section{CONCLUSION}

Data Envelopment Analysis (DEA) is a nonparametric approach used to measure the efficiency of an Economic Activity Unit (EAU). The objective of measuring the efficiency level is to compare the performance evaluation of one EAU with a comparable EAU. The efficient EAU will further form a line or frontier. The significance of measuring the efficiency using the DEA approach is to find the cause of any inefficiency in the EAU being studied, compare it with a similar EAU, and figure out the input or output variables that need to be improved to increase the efficiency score, which is called a potential improvement.

This study deals with the efficiency level of the EAU of banks operating according to the researched criteria in the ASEAN-5 countries. Results showed that every country in the
ASEAN-5 group, except Thailand, had technically efficient banks operating at 100\% during the studied period. On average, the efficiency level of all the banks surveyed in the ASEAN-5 was relatively high, because their relative efficiency scores were all close to $100 \%$.

The efficiency achievement of each variable in the ASEAN-5 banks is different in the first period (2006-2009) and the second period (20102013). This difference is because of the different economic conditions in the two periods. In the first period, the banks studied showed an increasing trend, in which Singapore shows the most efficient banking system for managing inputs and outputs. In contrast, the efficiency level of each bank's variables in the ASEAN-5 countries declined due to the high oil price, which led to declining efficiency scores for each country. 
The implication of this research is that the policy makers in the banking industry are expected to conduct evaluations, in an effort to improve the banks' performance, to make them more efficient and better in the next period. Then, considering that liberalization or deregulation in the financial services sector within ASEAN will surely cause a tightening in banking competition in ASEAN, this will encouraging the banks to operate more efficiently; such as deciding how much capital the banks must have so that the countries in ASEAN are able to prepare for it from now on. For banks that do not provide the required capital, each country may adopt policies such as the consolidation of those unqualified banks; so the planned liberalization of the financial services sector could have a good impact for ASEAN countries, and the role of the banks is still for them to be able to help increase the economic growth in each country in ASEAN.

\section{REFERENCES}

Abidin, Z., \& Endri, E. (2010). Kinerja efisiensi teknis bank pembangunan daerah: Pendekatan data envelopment analysis (DEA). Jurnal Akuntansi dan Keuangan, 11(1), 21-29.

Berger, A. N., \& Mester, L. J. (1997). Inside the black box: What explains differences in the efficiencies of financial institutions? Journal of Banking \& Finance, 21(7), 895947.

Charnes, A., Cooper, W. W., \& Rhodes, E. (1978). Measuring the efficiency of decision making units. European Journal of Operational Research, 2(6), 429-444.

Coelli, T.J., O'Donnell, P.R.C J., and Battese, G.E. (2005). An introduction to efficiency and productivity analysis ( $2^{\text {nd }} \mathrm{ed}$ ). United States of America: Springer Press.

Epstein, M. K., \& Henderson, J. C. (1989). Data envelopment analysis for managerial control and diagnosis. Decision Sciences, 20(1), 90119.

Farrell, M. J. (1957). The measurement of productive efficiency. Journal of the Royal Statistical Society, 253-290.

Fortune 500 (2016). Top pre-taxpProfit in 2014. Retrieved from http://fortune.com/global500/

Hadad, M. D., Santoso, W., Ilyas, D., and Mardanugraha, E. (2003). Analisis efisiensi industri perbankan Indonesia: Penggunaan metode nonparametrik data envelopment analysis (DEA). Research Paper Bank Indonesia, 7(5).

Kumbhakar S.C. and Lovell, C.A.K. (2000). Stochastic frontier analysis. Cambridge: Cambridge University Press.

Kost, F.E., and Rosenwig, J. E. (1979). Organization and management. A system and contingency approach. United States: McGraw-Hill Inc.

Muazaroh, Eduardus, T., Husnan, S., and Hanafi, M. M. (2012). Determinants of bank profit efficiency: Evidence from Indonesia. International Journal of Economics and Finance Studies, 4(2), 163-173.

Şahin, İ. E., Y1lmaz, B., \& Akgün, A. (2013). Measurement of efficiency in the Turkish banking sector in the 2009-2011 period: A DEA approach. Mediterranean Journal of Social Sciences, 4(10), 744.

Schwab, K. \& Sala-i-Martin, X. (2014). The global competitiveness report 2014-2015: Full data edition. World Economic Forum. Retrieved from http://www3.weforum.org/docs/WEF_Glob alCompetitivenessReport_2014-15.pdf

Suhartono, S. (2017). Productive efficiency of banks in ASEAN countries. Banks and Bank Systems, 12(2), 91-99.

Sufian, F., \& Habibullah, M. S. (2010). Developments in the efficiency of the Thailand banking sector: a DEA approach. International Journal of Development Issues, 9(3), 226-245. 
Wheelock, D. C., \& Wilson, P. W. (2000). Why do banks disappear? The determinants of US bank failures and acquisitions. Review of Economics and Statistics, 82(1), 127-138.
Wong, W. P., \& Deng, Q. (2016). Efficiency analysis of banks in ASEAN countries. Benchmarking: An International Journal, 23(7), 1798-1817.

Notice: The Journal of Indonesian Economy and Business and its Board of Editors are not responsible for any errors or flaws found in this article. The authors take full responsibility for their work. 